\title{
Toward a Responsible Capitalism: A Need for Financial Education and Social Finance
}

\author{
Caterina Galluccio \\ Università degli Studi Gabriele d'Annunzio di Chieti Pescara Via dei Vestini, Chieti, Italy \\ Email: caterina.gall uocio@unich.it
}

How to cite this paper: Galluccio, C. (2018). Toward a Responsible Capitalism: A Need for Financial Education and Social Finance. Sociology Mind, 8, 168-174. https://doi.org/10.4236/sm.2018.82014

Received: March 19, 2018

Accepted: April 27, 2018

Published: April 30, 2018

Copyright $\odot 2018$ by author and Scientific Research Publishing Inc. This work is licensed under the Creative Commons Attribution International License (CC BY 4.0).

http://creativecommons.org/licenses/by/4.0/

\begin{abstract}
Ralf Dahrendorf, in his paper After the Crisis. Back to the Protestant Ethic? sought to find the causes that made the society decide to adopt debt-based capitalism while dropping the savings capitalism. He used Max Weber's pieces to explain how thinking among the members of the society had transformed and how this contributed to the type of capitalism that had dominated the modern world. It is unquestionable that we cannot get into debt indefinitelysays Dahrendorf-but it's certainly not possible a return to the Protestant ethics. So the key point is in what he calls responsible capitalism that includes the concepts of responsibility and trust and requires that the satisfaction of individual needs falls under a sustainable economic development model. The thesis presented in this paper is that, in order to facilitate the emergence of a new mentality based on responsibility, there should be more economic and social participation that can take place on the one hand, through processes of economic socialization and financial education and, on the other hand, through the selection of alternative financial instruments, particularly the ones which belong to the social finance. The latter includes in the broad sense socially responsible finance and micro-credit and, strictly speaking, the more recent phenomena of crowd funding and social impact investments.
\end{abstract}

\section{Keywords}

Debt-Based Capitalism, Responsible Capitalism, Social Finance, Financial Education

\section{Introduction}

Ralf Dahrendorf, in his paper After the Crisis: Back to the Protestant Ethic? sought to find the causes that made the society decide to adopt debt-based capitalism while dropping the savings capitalism (Dahrendorf, 2010). He used Max 
Weber's pieces to explain how thinking among the members of the society had transformed and how this contributed to the type of capitalism that had dominated the modern world. The values that made people prefer the savings capitalism were appreciated because they had the ability to alter their lifestyle by observing the law, they could defer needs that were not urgent, they could work hard, and save while at the same time they could decide to invest (Bishop, 2012). However, the emergence of easy-credit capitalism saw consumers do away with the Protestant ethic since they believed that the accrued expenses could be paid at a later date. Subsequently, the society transitioned from a real economy to one that offered individuals virtual abilities that could yield a crisis. In the paper, The Protestant Ethic and the Spirit of Capitalism, Max Weber highlighted the manner in which cultural and economic aspects, and the values advocated for by the Protestants contributed to the rise of modern capitalism (Dahrendorf, 2010). In particular, Max Weber shed light on the ideas brought forth by the Calvinists and how this contributed to fueling the capitalism spirit. His focus on the tendency by most Protestants owning businesses made him consider that religion played a significant role when it came to the prevailing economic conditions. It is important to note that the Calvinists measured God's favor depending on the material possessions one had compared to others. The reasoning and beliefs of the Calvinists, therefore, created room for the sprouting of modern capitalism and the death of the economic system that traditionally existed. The predestination belief, which the Calvinists firmly held on, outlined that God predetermined the individuals who were saved and those who were damned. Taking an in-depth look into the matter of being saved raised structural issues and thereby forcing Calvinists to proceed with the perception that earthly possessions signified God's favor.

The adoption of debt-based capitalism necessitated the need for responsible capitalism which requires offering social finance and education to the members of the society. Besides, by receiving the required education, individuals will be better placed to make informed decisions since they are aware of the available social finance alternatives. Thus, they will be operating responsively when it comes to economic choices that bear cultural and social consequences (Klapper, Lusardi, \& Van Oudheusden, 2015).

The Protestant ethic came into play during the $16^{\text {th }}$ century and in particular within Europe (Bishop, 2012). The set of differences that existed between other Christian denominations and Protestants was evident. The Calvinists were part of the Protestants, and their religious philosophy was borne from one individual, John Calvin. It is important to note that the Calvinists, similar to other religions, saw God as the one who determined events that occur in the lives of people. Besides, the Calvinists believed that the precedent on whether one would succeed or fail when it came to getting saved had already been set by God. Therefore, having noted that this was the determiner to how the life of a person unfolded as time went by, the Calvinists saw it prudent to gather evidence on what indicated that one was saved or not (Miliband, 2012). Subsequently, this drew their atten- 
tion to the material possessions that measured the success of a person. The individuals who were wealthy were deemed to follow what was required of them by God and therefore received his favor in abundance. Over time, this belief led to the change in the manner the Calvinists perceived the economy. Specifically, capitalism became a phenomenon that would dictate the living standards of people. Whereas the members of other religions had similar beliefs regarding the capitalism issue, the Calvinists strictly followed the underlying principles of traditional capitalism. Weber took a close look at the history of capitalism and managed to link it with religion (Smith, 2011). However, Weber insisted that the relationship he had established between the origins of capitalism and religion were not conclusive but rather religion was among the factors that influenced it. Three pillars formed the Protestant Reformation, which guided the conduct of individuals. One of them was the fact that every individual stood an equal chance to sin and it was the same case for sin enslavement. Secondly, through the death of Jesus, the people were relieved the burden of sin, and upon believing in God, they would earn everlasting life in the kingdom of heaven. Lastly, the realization of the dream of everlasting life relied on God's favor upon an individual, which was determined by their belief in God. Individualism played a significant role in the Protestant Reformation. Moreover, this narrowed down to the efforts made by people in a move to receive individual salvation, which was different from that acquired by merely being a church member or through birth. For this matter, the significance attached to individualism assisted in promoting the traditional capitalism culture among Calvinists (Smith, 2011). Despite the strong adherence to the pillars of Protestant Reformation, there existed a dilemma that surrounded the hope of salvation. According to the predestination tenet, God has prior information on whether a person will succeed or fail to qualify to go to heaven. On the other side, the plan God has stored for his people is unknown, and no one understands where their fate lies. Thus, individuals will opt to lead a path that they perceive to be righteous whereby they will emulate those who have received God's favor as per their point of view. Solving the underlying dilemma requires people to conduct themselves properly in a move to be on the good side relative to God's favor. The ideal way of living would entail delaying non-urgent needs, working hard, saving and investing, maintaining sobriety, and operating within limits allowed by the law. Religiously following the recommended solutions will place a person in a good position of attaining entrepreneurial success. The profitability outcome will translate to one receiving favor from God. In the earlier years, profit making was regarded a sin, but the Protestant ethic made this activity an accepted virtue among members of the society. With time, thanks to the Protestant Ethic, there were increased cases of capital investment, conspicuous consumption, and the accumulation of wealth in a move to prove one was in God's good graces.

\section{Ralf Dahrendorf on the Protestant Ethic}

Weber, in his study, highlighted the issue of capitalism relative to religion and he 
talked about "beruf", vocation. The vocation that he addressed stemmed from the importance that an individual gave when it came to their work. It is important to note that vocation first featured in Protestantism and later formed a trait that fueled the capitalist spirit. In Protestantism, vocation signified a role accorded to a person by God, which needs to be handled in an organized way. Over the years, vocation was no longer a term familiar with Protestants only but also other entrepreneurs. Therefore, it entailed the obligation one had when it came to performing their responsibilities. Ralf Dahrendorf also weighed in on the Protestant Ethic. Dahrendorf viewed the 2008 crisis as a good example that illustrated how a capitalism culture could have adverse effects on the economy (Dahrendorf, 2010). They included public anger, a decline in the living standards, and sharp rises in taxation. The levels of poverty increased even after the crisis had ended owing to the fact that the society no longer attained economic growth. On the other hand, countries that had realized economic growth were not any different as the outstanding debts were paid out using the revenues earned. Governments tend to introduce more taxes, which make prices of basic commodities to lack stability, and this interferes with the consumption among the less affluent in the society. The common trends in society have shown that there has been the erosion of the Puritan culture and the urge for easy credit and consumerism has gone up. Specifically, the transition observed over time was from capitalism guided by savings then capitalism on the grounds of consumption followed and continued to the point where capitalism took the form of debt financing. The aging population can recall a period when savings were the order of the day. The United States witnessed an upsurge in capitalism through debt financing from the onset of World War I. On the contrary to the recent years where individuals paid the sums borrowed in installments; currently, people make money using the amounts borrowed. There has been a shift from the postponement of the non-urgent needs to "enjoy now, pay later." For this matter, people no longer operate in a real economy world but rather make out-of-pocket payments with amounts they do not own. Similarly, there has been a change in the manner people think. Dahrendorf acknowledged that it is not possible for people living in the modern world to return to the Protestant ethic. He warned that debt creation could not continue to infinity (Dahrendorf, 2010). Therefore, solving the underlying problem will require that people come up with new means on how to meet their demands through capitalism that adds value. For this matter, Dahrendorf admitted to the fact that economic success needs to be backed up by the expansion of rights. Therefore, this will pave room for holding a long-run mentality rather than one that covers a short period and subsequently attaining responsible capitalism.

\section{Responsible Capitalism: A Need for Financial Education and Social Finance}

Dahrendorf emphasized that responsible capitalism did not entail earning huge sums through transactions carried out in a deregulated market and further in- 
vesting them in civic and charitable development within the society (Dahrendorf, 2010). However, he did not rule out capitalist philanthropy only that it did not fall under the category of responsible capitalism. It is important to note that Dahrendorf attributed the responsible usage of funds acquired through capitalism to the level of accountability attached to them when it came to fulfilling social norms (Dahrendorf, 2010). For this reason, he defined responsible capitalism as prioritizing business relations with the society, coexisting well with workers, offering training to employees, and factoring environmental concerns when running routine procedures. Further, he saw the need for putting into consideration how firms operated in the other economic sectors ran their activities without facing any threats or externalities. Therefore, responsible capitalism includes a liberal environment that will allow other firms to thrive and involves the public service, charitable firms, and other voluntary agencies.

The key concepts-in what he calls responsible capitalism-are "responsibility" and "trust" that require that the satisfaction of individual needs falls under a sustainable economic development model.

To our opinion, the realization of this kind of responsible capitalism makes it mandatory for the involved stakeholders to initiate financial education and familiarize the members of the society with the available social finance options.

Financial Education is "the process by which financial consumers/investors improve their understanding of financial products, concepts and risks and, through information, instruction and/or objective advice, develop the skills and confidence to become more aware of financial risks and opportunities, to make informed choices, to know where to go for help, and to take other effective actions to improve their financial well-being" (OECD, 2016).

Each economic activity has its cultural and social consequences and further not all of them have noticeable effects. For this matter, there is the need for consciousness to avoid adverse outcomes that may arise due to making uninformed decisions. When it comes to the recommended ways through which financial awareness and education can yield responsible capitalism, then members of the society need to get the underlying risks and concepts of a financial product (Scott, 2015). They also ought to grasp the necessary skills that will assist them in exploiting the available opportunities. Hence, they will be better placed to know when to seek for advice from consultants and what they need to do in a bid to enhance their financial welfare.

Financial literacy is of great significance with regard to responsible capitalism, as it will enable individuals make informed decisions in any circumstance that revolves around their economic encounters. Concerning social finance (Nicholls, Paton, \& Emerson, 2016) it is a new type of finance in which the economic performance goes hand in hand with the social impact and economic performance is not a priority for the investor. It includes "social bonds", microcredit, ethical finance and crowd funding among other ethically accepted investments (Scott, 2015). Social financing prioritizes sources of funds where the social impact is directly proportional to the economic performance for an individual. The case is 
different for the investors since they ought to be rational to avoid imposing adverse social impacts on individuals interested with this kind of funding. Social bonds involve injecting funds into projects that will benefit the society and the returns are channeled to fund other related investments. For micro-credit, the people who are eligible to receive such funds need not provide the respective firms with collateral since this type of capitalization emphasizes on social inclusion as its primary objective (OECD, 2016). Not all companies that offer favorable capitalization can offer responsible capitalization to individuals. Specifically those excluded are the tobacco processors, those that pollute the environment, and those that have violated human rights in the past, armor shops, and alcohol breweries. Lastly, crowd funding involves utilizing the potential of reaching large multitudes of people using internet avenues to solicit funds for a social project (Klapper, Lusardi, \& Van Oudheusden, 2015). Programs such as recidivism could also be pivotal when it comes to responsible capitalization and will come a long way in helping the government make reasonable savings. Equally, non-governmental organizations may help in responsible capitalization especially when it comes to projects such as the rehabilitation of released inmates. Social impact bonds are quite different from social bonds as they do not have a predetermined interest rate. Owing to the high demand for social financing, social impact bonds lure private investors who are ready to effort help to members of the society.

\section{Conclusion}

Dahrenhorf shed light on how modern capitalism emerged with the primary focus being on the shift to debt-based capitalism from savings. The ability to access funds through debt capitalism meant that members of the society had entered into a virtual economy that was prone to facing crises. Dahrendorf made it clear that the debt-based capitalism would reach a point where it would force people to shift to means that entailed value addition in a bid to fulfill their needs. Despite noting this, he saw it was impossible for the restoration of the Protestant ethic and that the only possible way was to tend towards responsible capitalism.

The idea supported in this work is that the key concept is that of responsibility-according to the meaning given by methodological individualism-in other words the belief that each economic action taken by the social agent as a consumer, as an investor, as an entrepreneur or as a worker inevitably produces social and cultural consequences and the awareness of occurrence of these consequences is essential to produce a sustainable economic development model. The thesis presented here is that in order to facilitate the emergence of a new mentality based on responsibility there should be more economic and social participation that can take place on the one hand, through processes of economic socialization and financial education and, on the other hand, through the selection of alternative financial instruments, particularly the ones which belong to the social finance. 


\section{References}

Bishop, J. (2012). Lessons from the Emotivate Project for Increasing Take-Up of Big Society and Responsible Capitalism Initiatives. In P. M. Pumilia-Gnarini, E. Favaron, E. Pacetti, J. Bishop, \& L. Guerra (Eds.), Didactic Strategies and Technologies for Education: Incorporating Advancements (pp. 208-217), Hershey, PA: IGI Global.

Dahrendorf, R. (2010). After the Crisis: Back to the Protestant Ethic? Six Critical Observations. Max Weber Studies, 10, 11-21. https://doi.org/10.15543/MWS/2010/1/3

Klapper, L., Lusardi, A., \& Van Oudheusden, P. (2015). Financial Literacy around the World. Washington DC: Standard \& Poor's Ratings Services Global Financial Literacy Survey.

Miliband, E. (2012). Building a Responsible Capitalism. Juncture, 19, 17-25. https://doi.org/10.1111/j.1744-540X.2012.00677.x

Nicholls, A., Paton, R., \& Emerson, J. (Eds.) (2016) Social Finance. Oxford: Oxford University Press.

OECD (2016). Financial Education in Europe: Trends and Recent Developments. Paris: OECD Publishing.

Scott, P. (2015). Emerging social Finance Education Values. Toronto: Ontario Publishers.

Smith, R. E. (2011). Defining Corporate Social Responsibility: A Systems Approach for Socially Responsible Capitalism. Pennsylvania: University of Pennsylvania. 